\title{
The Roles of Primary Cilia in Cardiovascular Diseases
}

\author{
Rajasekharreddy Pala ${ }^{1,2}{ }^{\mathbb{D}}$, Maha Jamal ${ }^{1}$, Qamar Alshammari ${ }^{1}$ and Surya M. Nauli ${ }^{1,2, *}$ \\ 1 Department of Biomedical \& Pharmaceutical Sciences, Harry and Diane Rinker Health Science Campus, \\ Chapman University, 9401 Jeronimo Road, Irvine, CA 92618-1908, USA; rrpala@chapman.edu (R.P.); \\ jamal106@mail.chapman.edu (M.J.); qalshammari@chapman.edu (Q.A.) \\ 2 Department of Medicine, University of California Irvine, Irvine, CA 92868, USA \\ * Correspondence: nauli@chapman.edu; Tel.: +1-714-516-5480; Fax: +1-714-516-5481
}

Received: 29 October 2018; Accepted: 23 November 2018; Published: 27 November 2018

\begin{abstract}
Primary cilia are microtubule-based organelles found in most mammalian cell types. Cilia act as sensory organelles that transmit extracellular clues into intracellular signals for molecular and cellular responses. Biochemical and molecular defects in primary cilia are associated with a wide range of diseases, termed ciliopathies, with phenotypes ranging from polycystic kidney disease, liver disorders, mental retardation, and obesity to cardiovascular diseases. Primary cilia in vascular endothelia protrude into the lumen of blood vessels and function as molecular switches for calcium $\left(\mathrm{Ca}^{2+}\right)$ and nitric oxide (NO) signaling. As mechanosensory organelles, endothelial cilia are involved in blood flow sensing. Dysfunction in endothelial cilia contributes to aberrant fluid-sensing and thus results in vascular disorders, including hypertension, aneurysm, and atherosclerosis. This review focuses on the most recent findings on the roles of endothelial primary cilia within vascular biology and alludes to the possibility of primary cilium as a therapeutic target for cardiovascular disorders.
\end{abstract}

Keywords: primary cilia; calcium; nitric oxide; biochemical signaling; hypertension; aneurysm; atherosclerosis

\section{Introduction}

Cilia have been studied for their motile functions of lung epithelium, sperm cells, as well as in other organisms (such as algae) [1]. These motile cilia, in most cases, have $9+2$ microtubule structural arrangement. Researchers have also gained interest in studying non-motile cilia [2]. Non-motile cilia also known as primary cilia have a $9+0$ microtubule structural arrangement. Defects in primary cilia could cause various life-threatening diseases in humans, such as neural tube defects, which result in numerous abnormalities of the brain and spinal cord in patients diagnosed with Meckel syndrome, for example [3]. Several studies have shown that primary cilia are recognized as mechanical and chemical sensory organelles which serve as antennae to transmit extracellular to intracellular signaling mechanisms. Because primary cilia act as sensory organelles by which cells sense and transduce extracellular signals [4], any defects in primary cilia function could potentially cause several diseases which are collectively known as 'ciliopathies' (Table 1). The list of human ciliopathies has increased in recent years [5,6]. Mutations in approximately 50 genes have revealed to alter ciliary assembly or function, and as many as 1000 different ciliary proteins are still with undetermined functions and required further investigation. Hence, abnormal ciliary proteins can be associated with a single organ dysfunction to systemic multiple organ complications depending on the type of cells affected [7].

Cilia dysfunction has been implicated in polycystic kidney disease (PKD), obesity, nephronophthisis, mental retardation, Bardet-Biedl syndrome, oral facial syndrome, vascular diseases and others [7]. Specifically, impaired primary cilia on endothelial cells have important clinical consequences and are associated with many vascular diseases $[8,9]$. Although it has been over a 
century since primary cilia have been visualized, the study of their mechano- and chemo-sensory roles remains relatively a new field of study. Additionally, studies on endothelial primary cilia function of the vascular system and primary cilia as a therapeutic target for vascular diseases are still limited. In this review, the roles of primary cilia will be discussed with emphasis on the cardiovascular diseases [10-13]. Hence, it is important to have a clear understanding about ciliary structure and functional ciliary proteins to investigate how cilia dysfunction can contribute to vascular disorders of hypertension, aneurysm and atherosclerosis.

Table 1. Ciliary function and disease relevance.

\begin{tabular}{lll}
\hline Function & Disease Relevance & Reference \\
\hline Nodal flow sensing & Situs inversus; Situs ambiguous; Situs isomerism & {$[14,15]$} \\
Mechano-sensing & Kidney, Liver, and Pancreas Diseases & {$[16-18]$} \\
Shear stress sensing & Hypertension; Atherosclerosis; Aneurysm formation & {$[10-13]$} \\
Osmolarity sensing & Respiratory diseases; Infertility & {$[19,20]$} \\
Gravitational sensing & Osteoporosis; Chondroporosis & {$[21-23]$} \\
Olfaction sensing & Anosmia; Hyposmia & {$[24,25]$} \\
Light sensing & Retinitis pigmentosa; Blindness & {$[26-28]$} \\
Chemo-sensing & Nephrocystin; Diabetes; Obesity & {$[29-31]$} \\
Neurotransmitter sensing & Impaired brain plasticity & {$[32]$} \\
Developmental regulatory sensing & Developmental defects; Cancer & {$[33-35]$} \\
Pressure sensing & Bone maintenance, development & {$[22,36,37]$} \\
\hline
\end{tabular}

\section{Cilia Structure}

A cilium is considered as a cellular organelle, which is primarily composed of a membrane, soluble compartment, axoneme, basal body, and ciliary tip [38]. A cilium extends from a basal body complex, which is mainly composed of two centrioles. One of the centrioles is known as the mother centriole, to which the ciliary axoneme is ingrained beneath the cell membrane. The cilium structure contains the microtubular portions of cytoskeletal core unit called the axoneme (Figure 1). The axonemal structure contains nine peripheral doublet microtubules, which are made of alpha- and beta-tubulins and are post-translationally acetylated to support the long cilia structure [39-41]. The non-motile axoneme structure lacks the central pair of microtubules $(9+0)[42,43]$. In the blastocyst nodal cilia, the axoneme lacks the central pair of microtubules $(9+0)$ but shows motility. This exception requires both dynein arms for motility [44]. Of note is that the lack of radial spokes induces rotational motion instead of beating motion, suggesting that the absence of radial spokes allows nodal cilia to rotate unidirectionally but, as a trade-off, renders them ultrastructurally fragile [44]. While in most cases of motile cilia, the axoneme contains nine peripheral doublet microtubules and a central pair of microtubules $(9+2)$ [45]. There is a connection between the microtubular portion of the cytoskeleton and the ciliary axoneme, and the disruption of cytoplasmic microtubules or actin filaments, which could affect microtubules assembly resulting in the loss of ciliary structural integrity and mechanosensory function [46-48]. On the other hand, protein entering and exiting through cilium is controlled by a proteomic barrier at the ciliary base that encompasses a transition zone which separates cytosol from the cilia [49-52]. The ciliary membrane is connected with the plasma membrane but possesses a lipid bilayer composition that differs from the plasma membrane compositions [53]. The periciliary membrane, also known as the transition-membrane, connects ciliary and plasma membrane to form the ciliary pocket $[54,55]$. In addition to its fundamental structural role, the basal body connected to the transition-membrane is thought to regulate protein entry and exit from the ciliary compartment. Furthermore, the mechanoreceptors, protein transporters, sensory proteins and ligand-gated ion channels are involved in signal transduction enclosed within the ciliary membrane. The axoneme allows the intraflagellar signaling and intraflagellar transport (IFT) activities along with ciliary shaft using the soluble compartment, also called cilioplasm. Primary cilium lacking ribosomes is incapable of producing its own proteins required for the elongation and continuous turnover of axoneme 
necessary for self-safeguarding. Moreover, each part of this cilia structure is crucial to support various signaling molecules. Some of the more established cilia-dependent signaling pathways are already described [38].

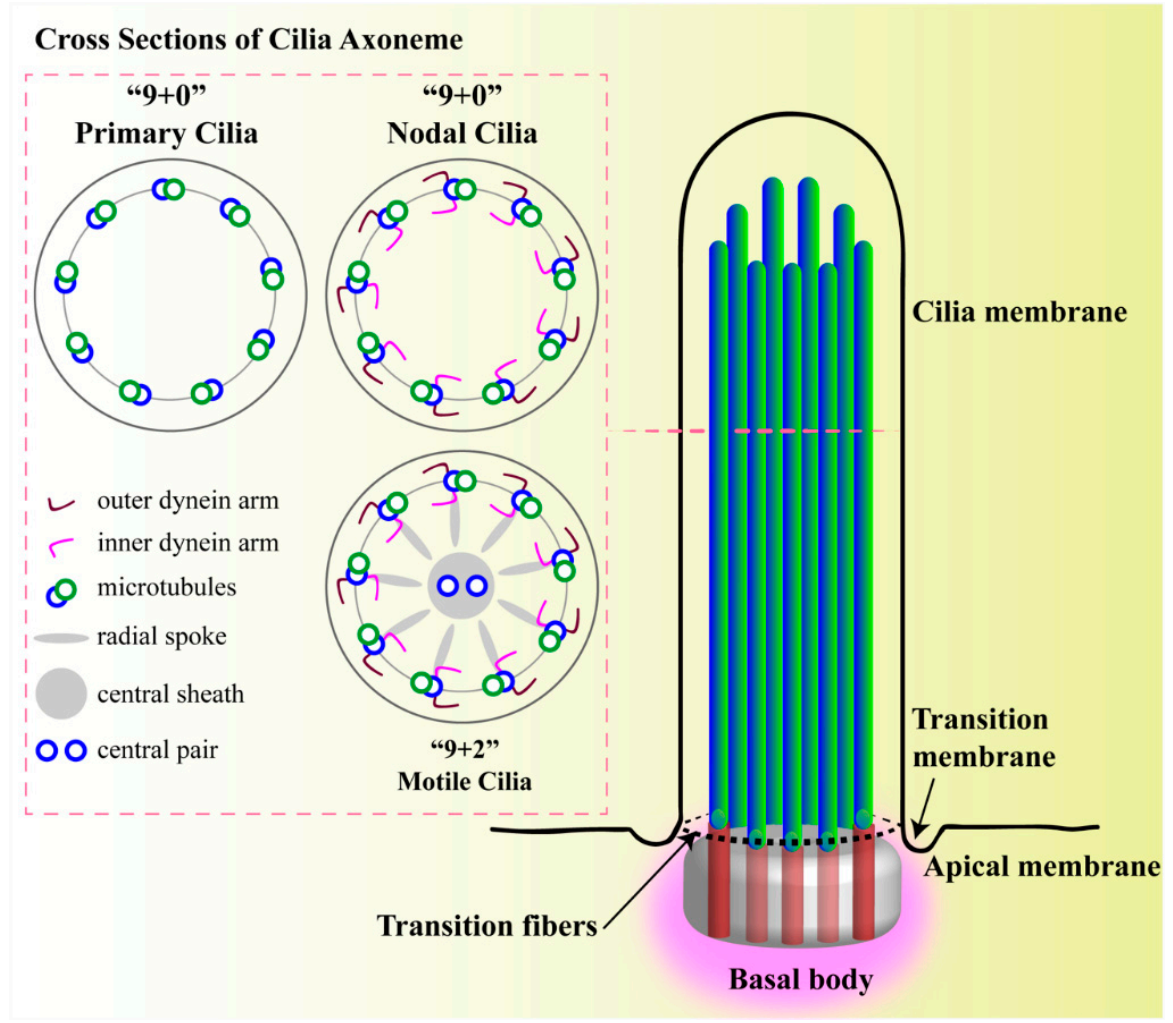

Figure 1. Structure of primary cilium. A cilium is a membrane-bound structure and composed of multiple central pairs of microtubules (axoneme) running from the basal body. A basal body is a microtubule-based structure composed of mother and daughter centrioles. The ciliary membrane and axoneme contributes to the upper part of the cilium. The ciliary membrane is continuous with the cell membrane, but they have their own proteins, ion channels and/or receptors. The ciliary skeleton may have $9+0$ or $9+2$ axoneme compositions. Most $9+0$ cilia lack inner and outer dynein arms, radial spokes, and central sheath and are commonly referred as non-motile primary cilia. Some $9+0$ cilia lack the central microtubule only and are motile. Between the cell membrane and cilium, there is a transition-membrane at the junction of the basal body acting as a barrier for molecules to enter or exit from the primary cilium.

\section{Primary Cilia as a Blood Flow Sensor}

Flow sensing by the cilia permit cells to sense blood flow along the blood vessels, urine flow through kidneys, bile acid in the liver, pancreatic secretions in the duodenum, nodal flow in Hansen's node (the site which determines the patterns the anterior-posterior axis of the embryo during gastrulation), interstitial fluid flow within the bone canaliculi, and potentially other systems/organs [56]. The function of the vascular system depends on the mechanical fluid flow signaling from the blood flow. Several studies have also reported that the presence of primary cilia in major circulatory systems including endocardia [13,57], arteries [58,59], veins [60], corneal endothelium [61,62], and smooth muscle cells of both arterial and airway endothelia [63,64]. The continuous contraction and relaxation of smooth muscle cells produce changes in the blood vessels diameter, which is important for normal blood flow [65-67]. Increase in vascular stiffness is a major cause of hypertension, which leads to complications including ventricular hypertrophy, vascular aneurysm and atherosclerosis [68-72]. These changes suggest that smooth muscle cells or neuronal regulations are important in regulating the vascular tone in addition to the mechanical fluid-flow 
within the blood vessel. The regulation of circulatory function is acquired by neuronal regulators through central and/or peripheral neurons [73-75].

The mechanical fluid-flow provides local regulation or autoregulation within a blood vessel. For example, autoregulation is required to achieve immediate blood flow control in specified area of the tissue. Autoregulation is independent of the neighboring tissues and has little to no effect on the surrounding tissues [76,77]. In an isolated blood vessel, the sudden increase of transmural blood pressure causes a reduced vessel diameter [78-80], whereas high flow stress increases vessel diameter $[67,80-82]$. As such, the lining of the inner surface of vascular blood vessels are endothelial cells with primary cilia protrusions, which can sense changes in blood velocity and pressure and convert these mechanical signals into changes of vascular smooth muscle tone [83,84]. In a biophysical perspective, fluid-shear stress refers to the partial or frictional force of blood flow as it brushes against the vascular endothelia [85]. This frictional force is not stable because blood flow changes with each heart muscle contraction, resulting in pulsatile patterns of blood flow [85]. As a result, blood flow through a vessel creates different types of forces such as stretch, compression, cyclic strain, pressure and shear stress. While these forces may be practically impossible to differentiate in vivo, they can be independently studied in in vitro and ex vivo studies [86].

Our earlier studies show that the primary endothelial cilia act as a mechanosensor in in vitro (mouse aortic endothelial cells), ex vivo (isolated mouse arteries, blood vessels from human patients) and in vivo (mouse models) [11,12,58]. Ciliary length is also positively correlated with mechanosensory action. Blood vessels with relatively a low fluid force have longer cilia while blood vessels with a high fluid force are devoid of cilia or have very short cilia. In addition, the changes in fluid dynamics affect endothelial cilia distribution and depend on fluid-flow intensity with longer cilia present in lower fluid-flow areas [13,87]. This is because of the inability of primary cilia to stand against high levels of fluid flow, which results in ciliary disassembly and loss of intraflagellar transport which is necessary for ciliary reassembly [88]. Subsequently, the mechanosensing function of cilia in high fluid flow areas could be replaced by other mechanisms like glycocalyx to sense higher shear forces [89].

Primary cilia have a critical role in sensing the extracellular stimuli, such as odorant or chemical (chemosensory) and movement (mechanosensory). These stimulations are then translated into intracellular signals. As a mechanosensor, a primary cilium can sense the fluid-flow in multiple cell types including renal epithelial and vascular endothelial cells $[12,18,90]$. Polycystin-1 (PC1) and polycystin-2 (PC2) form a mechanosensory complex in the primary cilia. It is recently shown that the PC1 and PC2 form a complex and are assembled in a stoichiometry of 3 PC2 for every PC1 molecule [91]. The PC1 and PC2 complex detects the bending of the cilia by the fluid flow leading to an increase in $\mathrm{Ca}^{2+}$ influx and an inhibition of the regulated intramembrane proteolysis (RIP) of PC1 by keeping the signal transducer and activator of transcription (STAT) factor 6 and its coactivator P100 in a complex bound to PC1 tail [92,93]. This is how primary cilia is thought to promote proliferation and differentiation through fluid-shear stress. On the other hand, the absence or lack of flow as well as loss or dysfunction of cilia, PC1, or PC2 decrease $\mathrm{Ca}^{2+}$ influx and activate RIP that allows STAT6 and P100 to translocate to the nucleus and stimulate transcription resulting in uncontrolled cell proliferation and cyst formation [94,95]. In particular, PC1 and PC2 are widely expressed across the vasculature, and they are hypothesized to play a major role in the development, maintenance, and function of the myoelastic arteries [96-98]. These observations indicate a direct pathogenic role for both PC1 and PC2 in the vascular complications of hypertension, aneurysm and/or atherosclerosis.

\section{Role of Primary Cilia in Heart Development}

Nodal cilia probably have the earliest cilia function during embryonic development. During gastrulation period, both motile (nodal) and non-motile cilia at the embryonic node play an important role in regulating signaling cascades required for the formation of left-right asymmetry, a process which regulates the early stages of cardiogenesis and connection to the blood vessels [15,99-102]. Fluid flow plays an important role in trabeculation, cardiac cell proliferation, and formation of conduction system, 
in addition to changes in fluid-shear forces, which lead to cardiac diseases. Cilia in cardiomyocytes have a series of receptors, which take part in regulating cellular signaling mechanisms required for the continuous differentiation, morphogenesis and development of the heart [103-106]. Independent studies have established the important role of heart cilia in cardiac development. Defects in cilia structure or function lead to severe inherited cardiac diseases. Also, defects in cilia result in a variety of heart developmental defects such as arterial and ventricular septum defects $[107,108]$, abnormal looping, and remodeling of the heart tube into a multi-chambered organ [109-114] or myocardial wall disorganization [115]. Moreover, mice with a mutation in cilia structural gene ift88, kif3a or $k i f 3 b$ are characterized by severe heart phenotypes including hypoplasia of the endocardial cushions, a reduction in ventricular trabeculation, and an increase in volume of pericardial space including defective cardiac looping [102]. A variety of signaling pathways are involved directly or indirectly in heart development. For example, Hedgehog $(\mathrm{Hh})$ signaling coordinated by primary cilia in a variety of cells controls tissue patterning and promotes the activation of different transcriptional factors involved in different cellular signaling mechanisms during homeostasis in vertebrates $[116,117]$. As a result, defects in primary cilia Hh signaling leads to severe cardiac disorders including congenital heart diseases [118]. Another example of a signaling pathway which plays an important role in cardiac morphogenesis is the superfamily of Transforming Growth Factor $\beta$ /Bone Morphogenic Protein (TGF $\beta / B M P)$. TGF $\beta$ /BMP signaling network is involved in a wide range of cellular mechanisms and processes and is therefore fundamentally vital during tissue homeostasis and morphogenesis [119]. Recent studies show that primary cilia can regulate the canonical TGF $\beta$ signaling network through the activation of transcription factors Smad2/3 at the ciliary pocket [104]. Furthermore, the TGF $\beta$ ligand, TGF- $\beta 1$, stimulates the differentiation of stem cells into cardiomyocytes and that $1 f t 88 / \mathrm{Tg} 737$ ( $\mathrm{Tg} 737^{\circ \mathrm{rpk}}$ ) mouse embryonic fibroblasts are characterized by decreased TGF $\beta$ activity associated with reduced clathrin-dependent endocytosis activity at the ciliary base, suggesting that cardiac primary cilia play a direct role in regulating TGF $\beta$ signaling during cardiomyogenesis. Recent findings further show that platelet-derived growth factor receptor- $\alpha$ (PDGFR $\alpha$ ) localizes to primary cilia in mutant mouse heart, indicating that a portion of the PDGF signaling pathway is associated with cardiac primary cilia during cardiac morphogenesis and development [105]. The localization of PDGFR $\alpha$ causes downregulation of Hh signaling in primary cilia and causes diminished ventricular wall thickness and ventricular septal defect [105]. Further, mice studies show that mutated or the absence of PDGFR $\alpha$, consequences arise in prenatal mortality such as heart defects including weakened myocardium, thinned septa and valve, outflow tract, and aortic branch malformations [120-122]. Taken together, the PDGF signaling system might be specifically coordinated by cardiac primary cilia, potentially acting as signaling hubs facilitating the cross-talk between different signaling networks in order to coordinate cardiogenesis.

\section{Role of Primary Cilia in Biochemical Signaling and Hypertension}

As mechanosensory organelles, primary cilia depend on various receptors expressed on the ciliary membrane. Vascular endothelial cells lining the blood vessel wall are in continuous contact with blood flow forces. Activation of primary cilia by blood flow leads to the activation of PC1 and PC2 resulting in an intracellular $\mathrm{Ca}^{2+}$ signaling network involving calmodulin (CaM), calcium-dependent protein kinase $(\mathrm{PKC})$, serine-threonine kinase/protein kinase $\mathrm{B}(\mathrm{Akt} / \mathrm{PKB})$ and endothelial nitric oxide synthase (eNOS). Such biochemical reaction generates nitric oxide $(\mathrm{NO})$ leading to vasodilation (Figure 2). There are two major proposed mechanisms for primary cilia detection of blood flow forces [85]. The first suggests that ciliary bending occurs upon exposure to blood flow-pressure force, which triggers cytoskeletal distortion. The second suggests that cilia bending triggers activation of PC1 mechanosensory protein and $\mathrm{PC} 2$ cation $\mathrm{Ca}^{2+}$ channels. It is proposed that the increase in intracellular $\mathrm{Ca}^{2+}$ is caused by an increase in intraciliary $\mathrm{Ca}^{2+}[123]$, whereas another study has suggested that $\mathrm{Ca}^{2+}$ could be rallied in both directions between the cilia and the cytoplasm [124]. While differences in the intraciliary $\mathrm{Ca}^{2+}$ can be due to the sensitivity of the cilia-specific $\mathrm{Ca}^{2+}$ probes [125], both studies show a consensus that mechanosensing function of cilium involves cytosolic $\mathrm{Ca}^{2+}$ signaling as shown 
independently by other laboratories $[17,126,127]$. Thus, it is fair to assess that primary cilia are $\mathrm{Ca}^{2+}$-responsive mechanosensors that can trigger a diverse biochemical signaling.

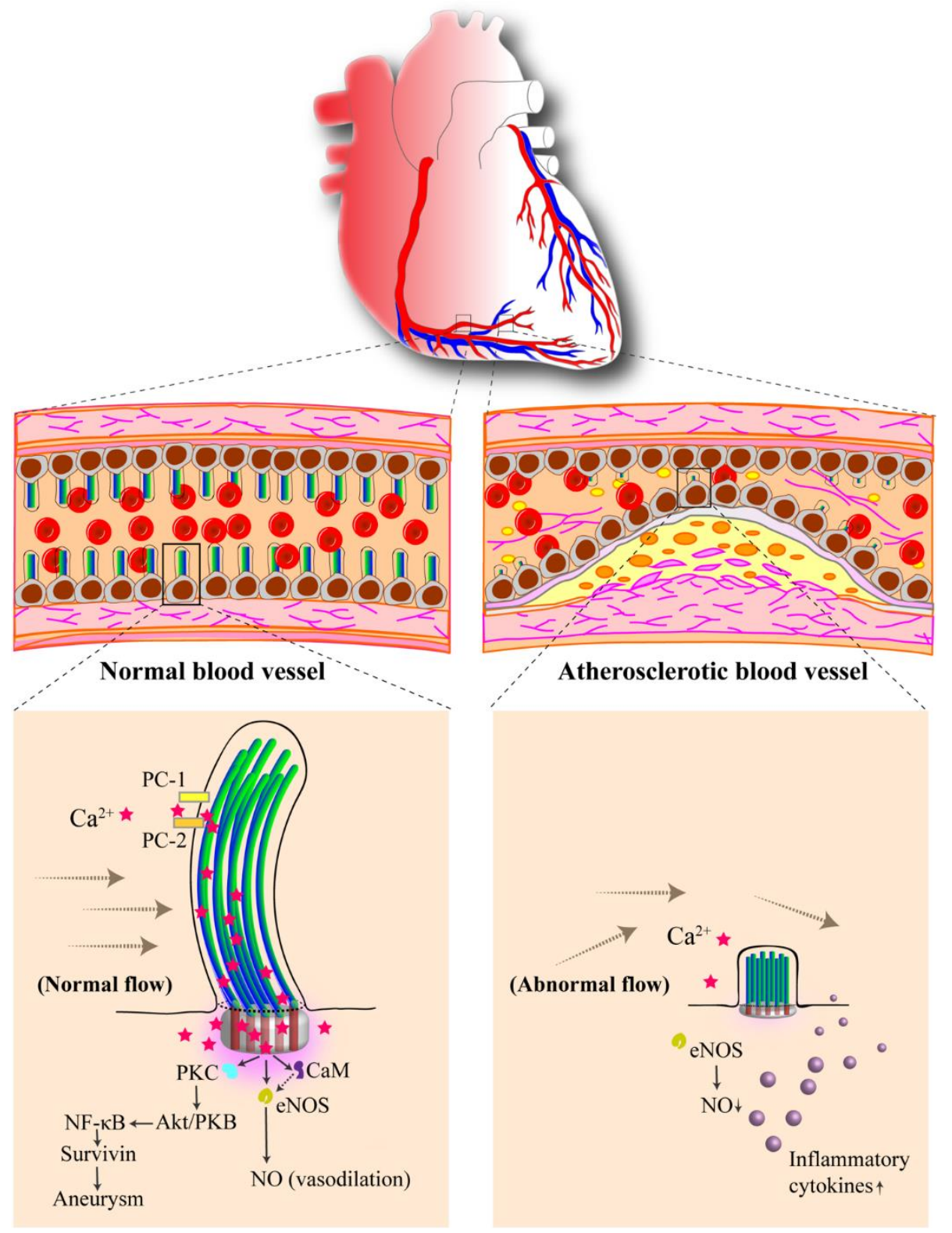

Figure 2. Vascular endothelial cilia sense the blood flow along the blood vessel. Primary cilia are structural compartments that house many mechanosensory proteins. Ciliary bending occurs upon blood-flow stimulation, and polycystin-1 (PC1) activates polycystin-2 (PC2), resulting in calcium $\left(\mathrm{Ca}^{2+}\right)$ influx. This generates a cascade of various protein activation and ultimately leads to endothelial nitric oxide synthase (eNOS) activation, producing vasodilator nitric oxide (NO). Calmodulin (CaM), calcium-dependent protein kinase (PKC) and serine-threonine kinase/protein kinase B (Akt/PKB) are involved in maintaining a healthy vascular structure. Abnormality in primary cilia has been proposed to promote vascular atherosclerotic formation.

Regardless, the cytosolic $\mathrm{Ca}^{2+}$ forms complexes with $\mathrm{CaM}$, and the $\mathrm{Ca}^{2+}-\mathrm{CaM}$ complex has been shown to indirectly activate eNOS through activation of the AKT/PKB signaling which activates AMPK, a known stimulator of eNOS [128]. Inhibition of $\mathrm{Ca}^{2+}$-dependent PKC, Akt/PKB, or CaM activity downstream of $\mathrm{Ca}^{2+}$ signaling have no effect on the flow induced intracellular $\mathrm{Ca}^{2+}$ increase, although there is a loss of NO synthesis [11]. This indicates that the $\mathrm{Ca}^{2+}$ signaling is upstream of 
the biochemical reaction in producing NO. Though eNOS triggering is principally a $\mathrm{Ca}^{2+}$-dependent process, some studies have suggested a $\mathrm{Ca}^{2+}$-independent pathway in $\mathrm{NO}$ biosynthesis is also possible. This $\mathrm{Ca}^{2+}$-independent pathway depends on the heat shock protein 90 (HSP90) $[129,130]$. HSP90 is a molecular chaperone, but it may also act as a signal transduction agent concomitant with eNOS in several systems, including the cardiovascular system. HSP90 also localizes to primary cilia [131]. Although its activation can increase eNOS action in presence of $\mathrm{Ca}^{2+}$-CaM $[129,132,133]$, it is unclear if cytosolic HSP90 is involved in this signaling pathway.

Dopamine signaling is considered to be an important signaling mechanism in the nervous, immune, cardiovascular, and renal systems [134]. Dopamine is an endogenous catecholamine hormone that is mainly produced in the brain and adrenal gland and is also biosynthesized in renal proximal tubules [135-137]. Dopamine, an endogenous hormone in the sympathetic nervous system, is known to be intricated in the regulation of hypertension. For example, abnormalities in dopamine signaling can contribute to high blood pressure in humans. The five G-protein-couple dopamine receptors (DR) are categorized into D1-like (DR1 and DR5) and D2-like (DR2, DR3, and DR4) families. Several in vitro and in vivo experiments confirm the presence of Dopamine 1-like receptors, DR1 and DR5, on primary cilia [59,138-141]. Studies have identified DR5 receptors in cultured mouse vascular endothelial cilia and mouse arteries in vivo. The DR modulates cilia mechanosensory function by altering fluid flow sensitivity. Rat studies also show that dis-integrin and metalloproteinase with thrombospondin motifs 16 (Adamts16) play a crucial role in blood pressure control. Further, interruption of the Adamts16 gene results in longer vascular endothelial primary cilia and significantly lower systolic blood pressure [58]. To date, there are no drugs available that specifically target DR in the cilia, but studies using agents selective for DR1-like receptor subtypes have shown vasodilatory outcomes in peripheral arteries. Activation of DR5 using dopamine increases ciliary length while inhibition of DR5 leads to the loss of ciliary sensory (chemo and mechano) activity [59]. These results are confirmed by challenging endothelial ciliary knockout cells, $P k d 1^{-/-}$and no or short cilia $T g 737^{\text {orpk/orpk }}$ with dopamine under static conditions, resulted in a considerably less $\mathrm{Ca}^{2+}$ influx than wild-type endothelial cells. As $\mathrm{Ca}^{2+}$ fluxes in these cells are often concomitant with activation of eNOS, the results may indicate a potential reestablishment of the missing vasodilatory reactions caused by a failed ciliary generation of NO biosynthesis. Likewise, there are DR within blood vessels in human, and activation of DR triggers a vasodilatory action [142].

Cilia dysfunction causes abnormal $\mathrm{Ca}^{2+}$ signaling and kidney disorders such as autosomal dominant polycystic kidney disease (ADPKD), which is a genetic disease caused by a mutation in ciliary PC1 or PC2 [6]. Cardiovascular malformations including high blood pressure and left ventricular hypertrophy notably contribute to mortality in ADPKD patients. A recent clinical review involving 1877 ADPKD patients shows that the use of antihypertensive medications in ADPKD patients have been increased from $32 \%$ in 1991 to $62 \%$ in 2008 [143]. This has important clinical consequences as another study has found that border-line hypertension in ADPKD patients show a better response with a dopamine precursor relatively to the angiotensin-converting enzyme inhibitor [144]. When individuals are perfused with $0.25-0.5 \mu \mathrm{g} / \mathrm{kg} / \mathrm{min}$ of dopamine, the results indicated an upward trend in flow-mediated dilation in ADPKD patients and reported a statistically significant decrease in hypertension [145]. It is currently studied to better understand if the dopamine-induced vasodilation is a cilia-dependent process [146]. A more recent study, however, seems to support the idea of cilia involvement in hypertension [147]. The study shows that cilia function is impaired in endothelial cells from patients with pulmonary arterial hypertension due to the inflammation, and cilia length plays an important role in response to inflammatory signaling, such as pro-inflammatory cytokines and/or anti-inflammatory interleukins. The results show that the pro-inflammatory cytokines help in increase cilia length and is PKA/PKC-dependent, whereas anti-inflammatory interleukins induce a reverse effect on cilia length. It is therefore postulated that the length of endothelial cilia is associated with endothelial function and pulmonary arterial pressure. 


\section{Role of Primary Cilia in Vascular Aneurysm}

An aneurysm is a formation of an abnormal swelling in a weak area of a blood vessel that can rupture, leading to bleeding and possibly to death. The most common arteries that can be affected by aneurysm are cerebral arteries and aortic artery. Aneurysm formation and rupture are considered one of the major complications associated with ADPKD, in which PC1 is required for structural integrity of blood vessel [148]. Thus, PC1 and PC2 functions are required in blood vessels [97,98,149], and, any abnormalities in either protein leads to aneurysm formation [150]. Of note: In ADPKD patients, the aneurysm can occur in different arteries such as the aorta, splenic, coronary, and cerebral arteries [151-154].

Within the arteries, primary cilia play an important role in the structure and the function of endothelial cells $[12,60]$. Therefore, the absence or dysfunction of primary cilia can induce aneurysm formation and progression during vascular injuries $[10,155]$. Vascular aneurysms are associated with tissue remodeling due to unusual proliferation of the endothelial cell layers through the hemodynamic fluctuations in fluid-shear forces [156]. Endothelial cilia are required for shear stress-induced $\mathrm{Ca}^{2+}$ influx and NO signaling [11], and eNOS deficiency is the hallmark of endothelial dysfunction and associated with cardiovascular complications including aneurysm, indicating the protective role of eNOS [157]. Primary cilia regulate endothelial actin organization and focal adhesion assembly that can affect directional migration and cell permeability through hsp27 and Notch/foxc1b signaling $[158,159]$. It is therefore thought that the mechano-sensation of primary cilia is essential in promoting proper vascular development.

Previously, we showed that the similarity of the pathogenesis between cyst formation and

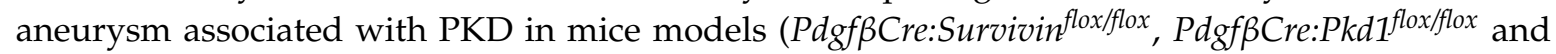
$\left.P d g f \beta C r e: T g 737^{f l o x} f f l o x\right)$. Dysfunction of the primary cilia induces an abnormal survivin expression that results in irregular cytokinesis leading to cell polyploidy, multi-mitotic spindle formation and aberrant cell division orientation. This abnormality in symmetrical cell division and cell ploidy leads to the extension of tissue architecture, developing cysts in the kidney and aneurysm in the vasculature [10]. PKC and Akt are downstream signaling messengers of primary cilia, and they regulate survivin expression following primary cilia activation. Akt is downstream of PKC and can regulate Nuclear Factor- $\mathrm{kB}$, which regulates the expression of survivin. All in all, the inability of primary endothelial cilia to respond to fluid flow can contribute to the vascular aneurysm.

\section{Role of Primary Cilia in Atherosclerosis}

Atherosclerosis plaques mainly develop in the arterial system with bifurcations, branch points, or the inner curvature of arched arteries. Atherosclerosis plaques are often observed at sites with low and oscillating fluid-flow within the embryonic cardiovascular system [13,57]. Plaques happen most frequently in areas of great curvature and branch points in addition to low fluid forces or non-unidirectional flow $[160,161]$. Like cilia which are present only at the regions of inner curvature of the artery arch [13], atherosclerotic plaques do not happen homogenously along the circulatory system. A recent report confirms that removing endothelial cilia from the vascular branch points causes abnormal fluid-flow responses that contribute to the atherosclerosis [162]. Moreover, exposure of endothelial cells to oscillatory fluid-flow results in the disengagement of eNOS, which promotes reactive oxygen species (ROS) formation rather than NO, leading to atherosclerosis plaque growth [163]. There is an upregulation of inflammatory gene expression in areas with disturbed blood flow, and this further promotes plaque formation and hyperlipidemia $[164,165]$.

The role of primary cilia in the development of atherosclerosis has been revealed in the apolipoprotein-E-deficient mouse model $\left(\mathrm{Apoe}^{-/-}\right)$with a high fat and cholesterol diet [162]. Increasing numbers of the endothelial primary cilia existed in atherogenesis areas under hyperlipidemia-induced

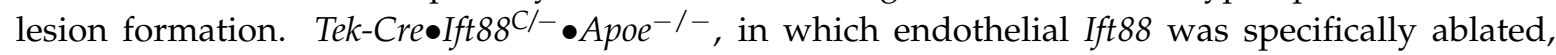
displayed a significantly greater increase in plaque formation compared to that established by their wildtype littermates. The lack of endothelial cilia in vascular branches result in significant upregulation 
lymphocyte markers, macrophage marker genes, along with proinflammatory cytokines [162]. Atherosclerosis lesions increase in the mice who lack endothelial cilia by $59 \%$ in females, and $67 \%$ in males as compared to the control mice. This is measured by counting atherosclerotic lesioned surface area. Furthermore, lacking endothelial cilia enhances inflammatory gene expression and a decrease in endothelial nitric oxide synthase activity. Hence, it is proposed that vascular endothelial cilia play an important role in control of atherosclerosis.

\section{Role of Primary Cilia in Cell Proliferation}

Not only do primary cilia provide a sensory signaling hub, they also play an important role in cell proliferation. Ciliogenesis begins at the G1/G0 phase of the cell cycle, and resorption or disassembly of cilia starts after the cell cycle re-entry. Primary cilia formation is influenced by the coordination of assembly/disassembly equilibrium, IFT system, and membrane trafficking [166]. Specifically, ciliogenesis involves multiple steps and is correlated with cell division. First, the centrosome travels to the cell surface and the basal body is formed by the mother centriole to nucleate ciliary axoneme at the G1/G0 phase of the cell cycle. This step which involves membrane docking is regulated by the distal appendage proteins, such as centrosomal protein 164 (Cep164). On the other hand, CP110, Ofd1, and trichoplein are negative regulators of ciliogenesis targeting ciliary extension. Second, elongation of the cilium and maintenance of ciliary length occur. This process is negatively regulated by Nde1 until mature primary cilium is formed. Third, upon cell cycle entry, ciliary resorption occurs followed by axoneme shortening. Ciliary disassembly is controlled by Aurora A-HDAC6, Nek2-Kif24, and Plk1-Kif2A pathways. Fourth, the basal body is released from cilia; thus, centrioles (centrosome) become free to act as microtubule organizing center (MTOC) or spindle poles during mitosis [166-168].

In tumors, cilia are not present on most proliferative cells suggesting that although cilia are not directly required during cell proliferation, they do play a key role in the entry and exit of mitosis [169171]. PC1 has been shown to mediate JAK/STAT pathway [172]. Ciliary PC1 is able to activate STAT3; when the cytoplasmic tail of PC1 is cleaved in response to fluid-flow, it can coactivate STAT-1, 3, and 6 as well as JAK2 [92]. The PC1 tail triggers several cytokines and growth factor signaling, amplifying the cellular response and potentially leading to an increase in L-arginine thus arresting cell proliferation.

Although the reason of the absence of cilia in cancer cells is not exactly known, this phenomenon is arguably not surprising given that the presence of cilia is a cell-cycle-dependent process [173]. Thus, cilia are not expected to be present in highly proliferative cells. However, what complicates the discussion is that primary cilia have also been reported in cancers, including in medulloblastoma [34, 174], basal cell [33] and gastroinstestinal stroma cells [175]. A recent study suggests a possibility of an enzymatic effect in cancer cells [176]. It is shown that posttranslational modification of ciliary tubulin is affected and resulted in less robust formation of primary cilia. Lacking proper posttranslational modification in ciliary exoneme may therefore increase a risk factor for cancer development [176].

\section{Conclusions and Perspective}

Both primary cilia structure and sensory functions are essential for normal tissue homeostasis and function. The in vitro and ex vivo fluid-flow studies have greatly advanced our knowledge of the chemo- and mechano-sensory function of primary cilia in cardiovascular systems. More studies are warranted towards clinical intervention for hypertension, aneurysm and atherosclerosis. Unfortunately, there are no pharmacological agents available that selectively target primary cilia. While this review mostly represents a small portion of possible connections between primary cilia and cardiovascular disorders, we may need a large-scale screening study to include potential pharmacological agents in order to understand whether or not targeting sensory functions of primary cilia would result in better cardiovascular outcomes.

Primary cilia are ubiquitously present in many organ systems, including the cardiovascular system. Emerging data suggest that cilium dysfunction is a primary cause in many cardiac and vascular disorders. Over the past years, researchers have provided tremendous advances in understanding 
of the basic cellular and molecular functions of primary cilia. Despite the fact that more research is needed, we should also extend ourselves by integrating the basic science knowledge into clinical considerations and perspectives. Otherwise, we are not able to see the forest because we are too focused on the trees.

Funding: This research was funded by Congressionally Directed Medical Research Program (grant ID: PR130153) and the National Institutes of Health (grant ID: HL131577).

Acknowledgments: Authors are grateful to Alisz Demecs for her editorial assistance.

Conflicts of Interest: The authors declare no conflict of interest.

\section{References}

1. Rosenbaum, J.L.; Witman, G.B. Intraflagellar transport. Nat. Rev. Mol. Cell Biol. 2002, 3, 813-825. [CrossRef] [PubMed]

2. Hua, K.; Ferland, R.J. Primary cilia proteins: Ciliary and extraciliary sites and functions. Cell. Mol. Life Sci. 2018, 75, 1521-1540. [CrossRef] [PubMed]

3. Hartill, V.; Szymanska, K.; Sharif, S.M.; Wheway, G.; Johnson, C.A. Meckel-Gruber Syndrome: An Update on Diagnosis, Clinical Management, and Research Advances. Front. Pediatr. 2017, 5, 244. [CrossRef] [PubMed]

4. Prasad, R.M.; Jin, X.; Nauli, S.M. Sensing a sensor: Identifying the mechanosensory function of primary cilia. Biosensors (Basel) 2014, 4, 47-62. [CrossRef] [PubMed]

5. Waters, A.M.; Beales, P.L. Ciliopathies: An expanding disease spectrum. Pediatr. Nephrol. 2011, 26, 1039-1056. [CrossRef] [PubMed]

6. Yoder, B.K. Role of primary cilia in the pathogenesis of polycystic kidney disease. J. Am. Soc. Nephrol. 2007, 18, 1381-1388. [CrossRef] [PubMed]

7. Badano, J.L.; Mitsuma, N.; Beales, P.L.; Katsanis, N. The ciliopathies: An emerging class of human genetic disorders. Annu. Rev. Genet. Hum. 2006, 7, 125-148. [CrossRef] [PubMed]

8. Luu, V.Z.; Chowdhury, B.; Al-Omran, M.; Hess, D.A.; Verma, S. Role of endothelial primary cilia as fluid mechanosensors on vascular health. Atherosclerosis 2018, 275, 196-204. [CrossRef] [PubMed]

9. Mohieldin, A.M.; Zubayer, H.S.; Al Omran, A.J.; Saternos, H.C.; Zarban, A.A.; Nauli, S.M.; AbouAlaiwi, W.A. Vascular Endothelial Primary Cilia: Mechanosensation and Hypertension. Curr. Hypertens. Rev. 2016, 12, 57-67. [CrossRef] [PubMed]

10. Aboualaiwi, W.A.; Muntean, B.S.; Ratnam, S.; Joe, B.; Liu, L.; Booth, R.L.; Rodriguez, I.; Herbert, B.S.; Bacallao, R.L.; Fruttiger, M.; et al. Survivin-induced abnormal ploidy contributes to cystic kidney and aneurysm formation. Circulation 2014, 129, 660-672. [CrossRef] [PubMed]

11. AbouAlaiwi, W.A.; Takahashi, M.; Mell, B.R.; Jones, T.J;; Ratnam, S.; Kolb, R.J.; Nauli, S.M. Ciliary polycystin-2 is a mechanosensitive calcium channel involved in nitric oxide signaling cascades. Circ. Res. 2009, 104, 860-869. [CrossRef] [PubMed]

12. Nauli, S.M.; Kawanabe, Y.; Kaminski, J.J.; Pearce, W.J.; Ingber, D.E.; Zhou, J. Endothelial cilia are fluid shear sensors that regulate calcium signaling and nitric oxide production through polycystin-1. Circulation 2008, 117, 1161-1171. [CrossRef] [PubMed]

13. Van der Heiden, K.; Hierck, B.P.; Krams, R.; de Crom, R.; Cheng, C.; Baiker, M.; Pourquie, M.J.; Alkemade, F.E.; DeRuiter, M.C.; Gittenberger-de Groot, A.C.; et al. Endothelial primary cilia in areas of disturbed flow are at the base of atherosclerosis. Atherosclerosis 2008, 196, 542-550. [CrossRef] [PubMed]

14. Karcher, C.; Fischer, A.; Schweickert, A.; Bitzer, E.; Horie, S.; Witzgall, R.; Blum, M. Lack of a laterality phenotype in Pkd1 knock-out embryos correlates with absence of polycystin-1 in nodal cilia. Differentiation 2005, 73, 425-432. [CrossRef] [PubMed]

15. McGrath, J.; Somlo, S.; Makova, S.; Tian, X.; Brueckner, M. Two populations of node monocilia initiate left-right asymmetry in the mouse. Cell 2003, 114, 61-73. [CrossRef]

16. Cano, D.A.; Sekine, S.; Hebrok, M. Primary cilia deletion in pancreatic epithelial cells results in cyst formation and pancreatitis. Gastroenterology 2006, 131, 1856-1869. [CrossRef] [PubMed]

17. Masyuk, A.I.; Masyuk, T.V.; Splinter, P.L.; Huang, B.Q.; Stroope, A.J.; LaRusso, N.F. Cholangiocyte cilia detect changes in luminal fluid flow and transmit them into intracellular $\mathrm{Ca}^{2+}$ and cAMP signaling. Gastroenterology 2006, 131, 911-920. [CrossRef] [PubMed] 
18. Nauli, S.M.; Alenghat, F.J.; Luo, Y.; Williams, E.; Vassilev, P.; Li, X.; Elia, A.E.; Lu, W.; Brown, E.M.; Quinn, S.J.; et al. Polycystins 1 and 2 mediate mechanosensation in the primary cilium of kidney cells. Nat. Genet. 2003, 33, 129-137. [CrossRef] [PubMed]

19. Teilmann, S.C.; Christensen, S.T. Localization of the angiopoietin receptors Tie- 1 and Tie- 2 on the primary cilia in the female reproductive organs. Cell Biol. Int. 2005, 29, 340-346. [CrossRef] [PubMed]

20. Andrade, Y.N.; Fernandes, J.; Vazquez, E.; Fernandez-Fernandez, J.M.; Arniges, M.; Sanchez, T.M.; Villalon, M.; Valverde, M.A. TRPV4 channel is involved in the coupling of fluid viscosity changes to epithelial ciliary activity. J. Cell Biol. 2005, 168, 869-874. [CrossRef] [PubMed]

21. Moorman, S.J.; Shorr, A.Z. The primary cilium as a gravitational force transducer and a regulator of transcriptional noise. Dev. Dyn. 2008, 237, 1955-1959. [CrossRef] [PubMed]

22. Malone, A.M.; Anderson, C.T.; Tummala, P.; Kwon, R.Y.; Johnston, T.R.; Stearns, T.; Jacobs, C.R. Primary cilia mediate mechanosensing in bone cells by a calcium-independent mechanism. Proc. Natl. Acad. Sci. USA 2007, 104, 13325-13330. [CrossRef] [PubMed]

23. McGlashan, S.R.; Haycraft, C.J.; Jensen, C.G.; Yoder, B.K.; Poole, C.A. Articular cartilage and growth plate defects are associated with chondrocyte cytoskeletal abnormalities in Tg737orpk mice lacking the primary cilia protein polaris. Matrix Biol. 2007, 26, 234-246. [CrossRef] [PubMed]

24. Layman, W.S.; McEwen, D.P.; Beyer, L.A.; Lalani, S.R.; Fernbach, S.D.; Oh, E.; Swaroop, A.; Hegg, C.C.; Raphael, Y.; Martens, J.R.; et al. Defects in neural stem cell proliferation and olfaction in Chd7 deficient mice indicate a mechanism for hyposmia in human CHARGE syndrome. Hum. Mol. Genet. 2009, 18, 1909-1923. [CrossRef] [PubMed]

25. Kulaga, H.M.; Leitch, C.C.; Eichers, E.R.; Badano, J.L.; Lesemann, A.; Hoskins, B.E.; Lupski, J.R.; Beales, P.L.; Reed, R.R.; Katsanis, N. Loss of BBS proteins causes anosmia in humans and defects in olfactory cilia structure and function in the mouse. Nat. Genet. 2004, 36, 994-998. [CrossRef] [PubMed]

26. Ghosh, A.K.; Murga-Zamalloa, C.A.; Chan, L.; Hitchcock, P.F.; Swaroop, A.; Khanna, H. Human retinopathy-associated ciliary protein retinitis pigmentosa GTPase regulator mediates cilia-dependent vertebrate development. Hum. Mol. Genet. 2010, 19, 90-98. [CrossRef] [PubMed]

27. Moore, A.; Escudier, E.; Roger, G.; Tamalet, A.; Pelosse, B.; Marlin, S.; Clement, A.; Geremek, M.; Delaisi, B.; Bridoux, A.M.; et al. RPGR is mutated in patients with a complex $\mathrm{X}$ linked phenotype combining primary ciliary dyskinesia and retinitis pigmentosa. J. Med. Genet. 2006, 43, 326-333. [CrossRef] [PubMed]

28. Nishimura, D.Y.; Fath, M.; Mullins, R.F.; Searby, C.; Andrews, M.; Davis, R.; Andorf, J.L.; Mykytyn, K.; Swiderski, R.E.; Yang, B.; et al. Bbs2-null mice have neurosensory deficits, a defect in social dominance, and retinopathy associated with mislocalization of rhodopsin. Proc. Natl. Acad. Sci. USA 2004, 101, 16588-16593. [CrossRef] [PubMed]

29. Davenport, J.R.; Watts, A.J.; Roper, V.C.; Croyle, M.J.; van Groen, T.; Wyss, J.M.; Nagy, T.R.; Kesterson, R.A.; Yoder, B.K. Disruption of intraflagellar transport in adult mice leads to obesity and slow-onset cystic kidney disease. Curr. Biol. 2007, 17, 1586-1594. [CrossRef] [PubMed]

30. Winkelbauer, M.E.; Schafer, J.C.; Haycraft, C.J.; Swoboda, P.; Yoder, B.K. The C. elegans homologs of nephrocystin-1 and nephrocystin-4 are cilia transition zone proteins involved in chemosensory perception. J. Cell Sci. 2005, 118, 5575-5587. [CrossRef] [PubMed]

31. Hearn, T.; Spalluto, C.; Phillips, V.J.; Renforth, G.L.; Copin, N.; Hanley, N.A.; Wilson, D.I. Subcellular localization of ALMS1 supports involvement of centrosome and basal body dysfunction in the pathogenesis of obesity, insulin resistance, and type 2 diabetes. Diabetes 2005, 54, 1581-1587. [CrossRef] [PubMed]

32. Einstein, E.B.; Patterson, C.A.; Hon, B.J.; Regan, K.A.; Reddi, J.; Melnikoff, D.E.; Mateer, M.J.; Schulz, S.; Johnson, B.N.; Tallent, M.K. Somatostatin signaling in neuronal cilia is critical for object recognition memory. J. Neurosci. 2010, 30, 4306-4314. [CrossRef] [PubMed]

33. Wong, S.Y.; Seol, A.D.; So, P.L.; Ermilov, A.N.; Bichakjian, C.K.; Epstein, E.H., Jr.; Dlugosz, A.A.; Reiter, J.F. Primary cilia can both mediate and suppress Hedgehog pathway-dependent tumorigenesis. Nat. Med. 2009, 15, 1055-1061. [CrossRef] [PubMed]

34. Han, Y.G.; Kim, H.J.; Dlugosz, A.A.; Ellison, D.W.; Gilbertson, R.J.; Alvarez-Buylla, A. Dual and opposing roles of primary cilia in medulloblastoma development. Nat. Med. 2009, 15, 1062-1065. [CrossRef] [PubMed]

35. Christensen, S.T.; Pedersen, S.F.; Satir, P.; Veland, I.R.; Schneider, L. The primary cilium coordinates signaling pathways in cell cycle control and migration during development and tissue repair. Curr. Top. Dev. Biol. 2008, 85, 261-301. [CrossRef] [PubMed] 
36. Hoey, D.A.; Tormey, S.; Ramcharan, S.; O’Brien, F.J.; Jacobs, C.R. Primary cilia-mediated mechanotransduction in human mesenchymal stem cells. Stem Cells 2012, 30, 2561-2570. [CrossRef] [PubMed]

37. Xiao, Z.; Zhang, S.; Mahlios, J.; Zhou, G.; Magenheimer, B.S.; Guo, D.; Dallas, S.L.; Maser, R.; Calvet, J.P.; Bonewald, L.; et al. Cilia-like structures and polycystin-1 in osteoblasts/osteocytes and associated abnormalities in skeletogenesis and Runx2 expression. J. Biol. Chem. 2006, 281, 30884-30895. [CrossRef] [PubMed]

38. Pala, R.; Alomari, N.; Nauli, S.M. Primary Cilium-Dependent Signaling Mechanisms. Int. J. Mol. Sci. 2017, 18, 2272. [CrossRef] [PubMed]

39. Berbari, N.F.; Sharma, N.; Malarkey, E.B.; Pieczynski, J.N.; Boddu, R.; Gaertig, J.; Guay-Woodford, L.; Yoder, B.K. Microtubule modifications and stability are altered by cilia perturbation and in cystic kidney disease. Cytoskeleton (Hoboken) 2013, 70, 24-31. [CrossRef] [PubMed]

40. Cueva, J.G.; Hsin, J.; Huang, K.C.; Goodman, M.B. Posttranslational acetylation of alpha-tubulin constrains protofilament number in native microtubules. Curr. Biol. 2012, 22, 1066-1074. [CrossRef] [PubMed]

41. Shida, T.; Cueva, J.G.; Xu, Z.; Goodman, M.B.; Nachury, M.V. The major alpha-tubulin K40 acetyltransferase alphaTAT1 promotes rapid ciliogenesis and efficient mechanosensation. Proc. Natl. Acad. Sci. USA 2010, 107, 21517-21522. [CrossRef] [PubMed]

42. Takeda, S.; Narita, K. Structure and function of vertebrate cilia, towards a new taxonomy. Differentiation 2012, 83, 41. [CrossRef] [PubMed]

43. Aughsteen, A.A. The ultrastructure of primary cilia in the endocrine and excretory duct cells of the pancreas of mice and rats. Eur. J. Morphol. 2001, 39, 277-283. [CrossRef] [PubMed]

44. Shinohara, K.; Chen, D.; Nishida, T.; Misaki, K.; Yonemura, S.; Hamada, H. Absence of Radial Spokes in Mouse Node Cilia Is Required for Rotational Movement but Confers Ultrastructural Instability as a Trade-Off. Dev. Cell 2015, 35, 236-246. [CrossRef] [PubMed]

45. Zhang, M.; Assouline, J.G. Cilia containing $9+2$ structures grown from immortalized cells. Cell Res. 2007, 17, 537-545. [CrossRef] [PubMed]

46. Drummond, M.L.; Li, M.; Tarapore, E.; Nguyen, T.T.L.; Barouni, B.J.; Cruz, S.; Tan, K.C.; Oro, A.E.; Atwood, S.X. Actin polymerization controls cilia-mediated signaling. J. Cell Biol. 2018, 217, 3255-3266. [CrossRef] [PubMed]

47. Hierck, B.P.; Van der Heiden, K.; Alkemade, F.E.; Van de Pas, S.; Van Thienen, J.V.; Groenendijk, B.C.; Bax, W.H.; Van der Laarse, A.; Deruiter, M.C.; Horrevoets, A.J.; et al. Primary cilia sensitize endothelial cells for fluid shear stress. Dev. Dyn. 2008, 237, 725-735. [CrossRef] [PubMed]

48. Alenghat, F.J.; Nauli, S.M.; Kolb, R.; Zhou, J.; Ingber, D.E. Global cytoskeletal control of mechanotransduction in kidney epithelial cells. Exp. Cell Res. 2004, 301, 23-30. [CrossRef] [PubMed]

49. Takao, D.; Wang, L.; Boss, A.; Verhey, K.J. Protein Interaction Analysis Provides a Map of the Spatial and Temporal Organization of the Ciliary Gating Zone. Curr. Biol. 2017, 27, 2296-2306. [CrossRef] [PubMed]

50. Bachmann-Gagescu, R.; Dona, M.; Hetterschijt, L.; Tonnaer, E.; Peters, T.; de Vrieze, E.; Mans, D.A.; van Beersum, S.E.; Phelps, I.G.; Arts, H.H.; et al. The Ciliopathy Protein CC2D2A Associates with NINL and Functions in RAB8-MICAL3-Regulated Vesicle Trafficking. PLoS Genet. 2015, 11, e1005575. [CrossRef] [PubMed]

51. Gerhardt, C.; Lier, J.M.; Burmuhl, S.; Struchtrup, A.; Deutschmann, K.; Vetter, M.; Leu, T.; Reeg, S.; Grune, T.; Ruther, U. The transition zone protein Rpgrip1l regulates proteasomal activity at the primary cilium. J. Cell Biol. 2015, 210, 115-133. [CrossRef] [PubMed]

52. Garcia-Gonzalo, F.R.; Corbit, K.C.; Sirerol-Piquer, M.S.; Ramaswami, G.; Otto, E.A.; Noriega, T.R.; Seol, A.D.; Robinson, J.F.; Bennett, C.L.; Josifova, D.J.; et al. A transition zone complex regulates mammalian ciliogenesis and ciliary membrane composition. Nat. Genet. 2011, 43, 776-784. [CrossRef] [PubMed]

53. Janich, P.; Corbeil, D. GM1 and GM3 gangliosides highlight distinct lipid microdomains within the apical domain of epithelial cells. FEBS Lett. 2007, 581, 1783-1787. [CrossRef] [PubMed]

54. Lee, J.; Chung, Y.D. Ciliary subcompartments: How are they established and what are their functions? BMB Rep. 2015, 48, 380-387. [CrossRef] [PubMed]

55. Molla-Herman, A.; Ghossoub, R.; Blisnick, T.; Meunier, A.; Serres, C.; Silbermann, F.; Emmerson, C.; Romeo, K.; Bourdoncle, P.; Schmitt, A.; et al. The ciliary pocket: An endocytic membrane domain at the base of primary and motile cilia. J. Cell Sci. 2010, 123, 1785-1795. [CrossRef] [PubMed] 
56. Marshall, W.F.; Nonaka, S. Cilia: Tuning in to the cell's antenna. Curr. Biol. 2006, 16, 604-614. [CrossRef] [PubMed]

57. Van der Heiden, K.; Groenendijk, B.C.; Hierck, B.P.; Hogers, B.; Koerten, H.K.; Mommaas, A.M.; Gittenberger-de Groot, A.C.; Poelmann, R.E. Monocilia on chicken embryonic endocardium in low shear stress areas. Dev. Dyn. 2006, 235, 19-28. [CrossRef] [PubMed]

58. Gopalakrishnan, K.; Kumarasamy, S.; Abdul-Majeed, S.; Kalinoski, A.L.; Morgan, E.E.; Gohara, A.F.; Nauli, S.M.; Filipiak, W.E.; Saunders, T.L.; Joe, B. Targeted disruption of Adamts16 gene in a rat genetic model of hypertension. Proc. Natl. Acad. Sci. USA 2012, 109, 20555-20559. [CrossRef] [PubMed]

59. Abdul-Majeed, S.; Nauli, S.M. Dopamine receptor type 5 in the primary cilia has dual chemo- and mechano-sensory roles. Hypertension 2011, 58, 325-331. [CrossRef] [PubMed]

60. Iomini, C.; Tejada, K.; Mo, W.; Vaananen, H.; Piperno, G. Primary cilia of human endothelial cells disassemble under laminar shear stress. J. Cell Biol. 2004, 164, 811-817. [CrossRef] [PubMed]

61. Doughty, M.J. Changes in cell surface primary cilia and microvilli concurrent with measurements of fluid flow across the rabbit corneal endothelium ex vivo. Tissue Cell 1998, 30, 634-643. [CrossRef]

62. Gallagher, B.C. Primary cilia of the corneal endothelium. Am. J. Anat. 1980, 159, 475-484. [CrossRef] [PubMed]

63. Wu, J.; Du, H.; Wang, X.; Mei, C.; Sieck, G.C.; Qian, Q. Characterization of primary cilia in human airway smooth muscle cells. Chest 2009, 136, 561-570. [CrossRef] [PubMed]

64. Poole, C.A.; Jensen, C.G.; Snyder, J.A.; Gray, C.G.; Hermanutz, V.L.; Wheatley, D.N. Confocal analysis of primary cilia structure and colocalization with the Golgi apparatus in chondrocytes and aortic smooth muscle cells. Cell Biol. Int. 1997, 21, 483-494. [CrossRef] [PubMed]

65. Chistiakov, D.A.; Orekhov, A.N.; Bobryshev, Y.V. Effects of shear stress on endothelial cells: Go with the flow. Acta Physiol. (Oxf.) 2017, 219, 382-408. [CrossRef] [PubMed]

66. Giles, T.D.; Sander, G.E.; Nossaman, B.D.; Kadowitz, P.J. Impaired vasodilation in the pathogenesis of hypertension: Focus on nitric oxide, endothelial-derived hyperpolarizing factors, and prostaglandins. J. Clin. Hypertens. (Greenwich) 2012, 14, 198-205. [CrossRef] [PubMed]

67. Pyke, K.E.; Tschakovsky, M.E. The relationship between shear stress and flow-mediated dilatation: Implications for the assessment of endothelial function. J. Physiol. 2005, 568, 357-369. [CrossRef] [PubMed]

68. Sehgel, N.L.; Zhu, Y.; Sun, Z.; Trzeciakowski, J.P.; Hong, Z.; Hunter, W.C.; Vatner, D.E.; Meininger, G.A.; Vatner, S.F. Increased vascular smooth muscle cell stiffness: A novel mechanism for aortic stiffness in hypertension. Am. J. Physiol. Heart Circ. Physiol. 2013, 305, 1281-1287. [CrossRef] [PubMed]

69. Kadoglou, N.P.; Papadakis, I.; Moulakakis, K.G.; Ikonomidis, I.; Alepaki, M.; Moustardas, P.; Lampropoulos, S.; Karakitsos, P.; Lekakis, J.; Liapis, C.D. Arterial stiffness and novel biomarkers in patients with abdominal aortic aneurysms. Regul. Pept. 2012, 179, 50-54. [CrossRef] [PubMed]

70. Laurent, S.; Boutouyrie, P.; Asmar, R.; Gautier, I.; Laloux, B.; Guize, L.; Ducimetiere, P.; Benetos, A. Aortic stiffness is an independent predictor of all-cause and cardiovascular mortality in hypertensive patients. Hypertension 2001, 37, 1236-1241. [CrossRef] [PubMed]

71. Roman, M.J.; Ganau, A.; Saba, P.S.; Pini, R.; Pickering, T.G.; Devereux, R.B. Impact of arterial stiffening on left ventricular structure. Hypertension 2000, 36, 489-494. [CrossRef] [PubMed]

72. Stefanadis, C.; Wooley, C.F.; Bush, C.A.; Kolibash, A.J.; Boudoulas, H. Aortic distensibility abnormalities in coronary artery disease. Am. J. Cardiol. 1987, 59, 1300-1304. [CrossRef]

73. Taylor, E.W.; Jordan, D.; Coote, J.H. Central control of the cardiovascular and respiratory systems and their interactions in vertebrates. Physiol. Rev. 1999, 79, 855-916. [CrossRef] [PubMed]

74. Krimer, L.S.; Muly, E.C., 3rd; Williams, G.V.; Goldman-Rakic, P.S. Dopaminergic regulation of cerebral cortical microcirculation. Nat. Neurosci. 1998, 1, 286-289. [CrossRef] [PubMed]

75. Korner, P.I.; Head, G.A.; Badoer, E.; Bobik, A.; Angus, J.A. Role of brain amine transmitters and some neuromodulators in blood pressure, heart rate, and baroreflex control. J. Cardiovasc. Pharmacol. 1987, $10, \mathrm{~S} 1-\mathrm{S} 2$.

76. Rhee, C.J.; da Costa, C.S.; Austin, T.; Brady, K.M.; Czosnyka, M.; Lee, J.K. Neonatal cerebrovascular autoregulation. Pediatr. Res. 2018. [CrossRef] [PubMed]

77. Burke, M.; Pabbidi, M.R.; Farley, J.; Roman, R.J. Molecular mechanisms of renal blood flow autoregulation. Curr. Vasc. Pharmacol. 2014, 12, 845-858. [CrossRef] [PubMed] 
78. Spurrell, B.E.; Murphy, T.V.; Hill, M.A. Intraluminal pressure stimulates MAPK phosphorylation in arterioles: Temporal dissociation from myogenic contractile response. Am. J. Physiol. Heart Circ. Physiol. 2003, 285, 1764-1773. [CrossRef] [PubMed]

79. Bolz, S.; Pieperhoff, S.; De Wit, C.; Pohl, U. Chronic increases in transmural pressure reduce NO-mediated dilations in isolated resistance arteries of the hamster. Acta Physiol. Scand. 2000, 168, 113-117. [CrossRef] [PubMed]

80. Rubanyi, G.M. Ionic mechanisms involved in the flow- and pressure-sensor function of the endothelium. Z Kardiol 1991, 80, 91-94. [PubMed]

81. Raitakari, O.T.; Celermajer, D.S. Flow-mediated dilatation. Br. J. Clin. Pharmacol. 2000, 50, 397-404. [CrossRef] [PubMed]

82. Bevan, J.A. Shear stress, the endothelium and the balance between flow-induced contraction and dilation in animals and man. Int J. Microcirc. Clin. Exp. 1997, 17, 248-256. [CrossRef] [PubMed]

83. Chien, S. Effects of disturbed flow on endothelial cells. Ann. Biomed. Eng. 2008, 36, 554-562. [CrossRef] [PubMed]

84. Chien, S. Mechanotransduction and endothelial cell homeostasis: The wisdom of the cell. Am. J. Physiol. Heart Circ. Physiol. 2007, 292, 1209-1224. [CrossRef] [PubMed]

85. Ando, J.; Yamamoto, K. Flow detection and calcium signalling in vascular endothelial cells. Cardiovasc. Res. 2013, 99, 260-268. [CrossRef] [PubMed]

86. Nauli, S.M.; Jin, X.; Hierck, B.P. The mechanosensory role of primary cilia in vascular hypertension. Int. J. Vasc. Med. 2011, 2011, 376281. [CrossRef] [PubMed]

87. Sherpa, R.T.; Atkinson, K.F.; Ferreira, V.P.; Nauli, S.M. Rapamycin Increases Length and Mechanosensory Function of Primary Cilia in Renal Epithelial and Vascular Endothelial Cells. Int. Educ. Res. J. 2016, 2, 91-97. [PubMed]

88. Blitzer, A.L.; Panagis, L.; Gusella, G.L.; Danias, J.; Mlodzik, M.; Iomini, C. Primary cilia dynamics instruct tissue patterning and repair of corneal endothelium. Proc. Natl. Acad. Sci. USA 2011, 108, 2819-2824. [CrossRef] [PubMed]

89. Tarbell, J.M.; Pahakis, M.Y. Mechanotransduction and the glycocalyx. J. Intern. Med. 2006, 259, 339-350. [CrossRef] [PubMed]

90. Praetorius, H.A.; Spring, K.R. Removal of the MDCK cell primary cilium abolishes flow sensing. J. Membr. Biol. 2003, 191, 69-76. [CrossRef] [PubMed]

91. Su, Q.; Hu, F.; Ge, X.; Lei, J.; Yu, S.; Wang, T.; Zhou, Q.; Mei, C.; Shi, Y. Structure of the human PKD1-PKD2 complex. Science 2018, 361. [CrossRef] [PubMed]

92. Talbot, J.J.; Shillingford, J.M.; Vasanth, S.; Doerr, N.; Mukherjee, S.; Kinter, M.T.; Watnick, T.; Weimbs, T. Polycystin-1 regulates STAT activity by a dual mechanism. Proc. Natl. Acad. Sci. USA 2011, 108, 7985-7990. [CrossRef] [PubMed]

93. Low, S.H.; Vasanth, S.; Larson, C.H.; Mukherjee, S.; Sharma, N.; Kinter, M.T.; Kane, M.E.; Obara, T.; Weimbs, T. Polycystin-1, STAT6, and P100 function in a pathway that transduces ciliary mechanosensation and is activated in polycystic kidney disease. Dev. Cell 2006, 10, 57-69. [CrossRef] [PubMed]

94. Weimbs, T.; Olsan, E.E.; Talbot, J.J. Regulation of STATs by polycystin-1 and their role in polycystic kidney disease. JAKSTAT 2013, 2, e23650. [CrossRef] [PubMed]

95. Weimbs, T. Polycystic kidney disease and renal injury repair: Common pathways, fluid flow, and the function of polycystin-1. Am. J. Physiol. Renal. Physiol. 2007, 293, 1423-1432. [CrossRef] [PubMed]

96. Qian, Q.; Li, M.; Cai, Y.; Ward, C.J.; Somlo, S.; Harris, P.C.; Torres, V.E. Analysis of the polycystins in aortic vascular smooth muscle cells. J. Am. Soc. Nephrol. 2003, 14, 2280-2287. [CrossRef] [PubMed]

97. Torres, V.E.; Cai, Y.; Chen, X.; Wu, G.Q.; Geng, L.; Cleghorn, K.A.; Johnson, C.M.; Somlo, S. Vascular expression of polycystin-2. J. Am. Soc. Nephrol. 2001, 12, 1-9. [PubMed]

98. Griffin, M.D.; Torres, V.E.; Grande, J.P.; Kumar, R. Vascular expression of polycystin. J. Am. Soc. Nephrol. 1997, 8, 616-626. [PubMed]

99. Komatsu, Y.; Mishina, Y. Establishment of left-right asymmetry in vertebrate development: The node in mouse embryos. Cell. Mol. Life Sci. 2013, 70, 4659-4666. [CrossRef] [PubMed]

100. Norris, D.P. Cilia, calcium and the basis of left-right asymmetry. BMC Biol. 2012, 10, 102. [CrossRef] [PubMed] 
101. McGrath, J.; Brueckner, M. Cilia are at the heart of vertebrate left-right asymmetry. Curr. Opin. Genet. Dev. 2003, 13, 385-392. [CrossRef]

102. Nonaka, S.; Tanaka, Y.; Okada, Y.; Takeda, S.; Harada, A.; Kanai, Y.; Kido, M.; Hirokawa, N. Randomization of left-right asymmetry due to loss of nodal cilia generating leftward flow of extraembryonic fluid in mice lacking KIF3B motor protein. Cell 1998, 95, 829-837. [CrossRef]

103. Li, Y.; Klena, N.T.; Gabriel, G.C.; Liu, X.; Kim, A.J.; Lemke, K.; Chen, Y.; Chatterjee, B.; Devine, W.; Damerla, R.R.; et al. Global genetic analysis in mice unveils central role for cilia in congenital heart disease. Nature 2015, 521, 520-524. [CrossRef] [PubMed]

104. Clement, C.A.; Ajbro, K.D.; Koefoed, K.; Vestergaard, M.L.; Veland, I.R.; Henriques de Jesus, M.P.; Pedersen, L.B.; Benmerah, A.; Andersen, C.Y.; Larsen, L.A.; et al. TGF-beta signaling is associated with endocytosis at the pocket region of the primary cilium. Cell Rep. 2013, 3, 1806-1814. [CrossRef] [PubMed]

105. Gerhardt, C.; Lier, J.M.; Kuschel, S.; Ruther, U. The ciliary protein Ftm is required for ventricular wall and septal development. PLoS ONE 2013, 8, e57545. [CrossRef] [PubMed]

106. Clement, C.A.; Kristensen, S.G.; Mollgard, K.; Pazour, G.J.; Yoder, B.K.; Larsen, L.A.; Christensen, S.T. The primary cilium coordinates early cardiogenesis and hedgehog signaling in cardiomyocyte differentiation. J. Cell Sci. 2009, 122, 3070-3082. [CrossRef] [PubMed]

107. Sang, L.; Miller, J.J.; Corbit, K.C.; Giles, R.H.; Brauer, M.J.; Otto, E.A.; Baye, L.M.; Wen, X.; Scales, S.J.; Kwong, M.; et al. Mapping the NPHP-JBTS-MKS protein network reveals ciliopathy disease genes and pathways. Cell 2011, 145, 513-528. [CrossRef] [PubMed]

108. Wu, G.; Markowitz, G.S.; Li, L.; D’Agati, V.D.; Factor, S.M.; Geng, L.; Tibara, S.; Tuchman, J.; Cai, Y.; Park, J.H.; et al. Cardiac defects and renal failure in mice with targeted mutations in Pkd2. Nat. Genet. 2000, 24, 75-78. [CrossRef] [PubMed]

109. Onoufriadis, A.; Paff, T.; Antony, D.; Shoemark, A.; Micha, D.; Kuyt, B.; Schmidts, M.; Petridi, S.; Dankert-Roelse, J.E.; Haarman, E.G.; et al. Splice-site mutations in the axonemal outer dynein arm docking complex gene CCDC114 cause primary ciliary dyskinesia. Am. J. Hum. Genet. 2013, 92, 88-98. [CrossRef] [PubMed]

110. French, V.M.; van de Laar, I.M.; Wessels, M.W.; Rohe, C.; Roos-Hesselink, J.W.; Wang, G.; Frohn-Mulder, I.M.; Severijnen, L.A.; de Graaf, B.M.; Schot, R.; et al. NPHP4 variants are associated with pleiotropic heart malformations. Circ. Res. 2012, 110, 1564-1574. [CrossRef] [PubMed]

111. Fakhro, K.A.; Choi, M.; Ware, S.M.; Belmont, J.W.; Towbin, J.A.; Lifton, R.P.; Khokha, M.K.; Brueckner, M. Rare copy number variations in congenital heart disease patients identify unique genes in left-right patterning. Proc. Natl. Acad. Sci. USA 2011, 108, 2915-2920. [CrossRef] [PubMed]

112. Kinzel, D.; Boldt, K.; Davis, E.E.; Burtscher, I.; Trumbach, D.; Diplas, B.; Attie-Bitach, T.; Wurst, W.; Katsanis, N.; Ueffing, M.; et al. Pitchfork regulates primary cilia disassembly and left-right asymmetry. Dev. Cell 2010, 19, 66-77. [CrossRef] [PubMed]

113. Hadjantonakis, A.K.; Pisano, E.; Papaioannou, V.E. Tbx6 regulates left/right patterning in mouse embryos through effects on nodal cilia and perinodal signaling. PLoS ONE 2008, 3, e2511. [CrossRef] [PubMed]

114. Ramsdell, A.F. Left-right asymmetry and congenital cardiac defects: Getting to the heart of the matter in vertebrate left-right axis determination. Dev. Biol. 2005, 288, 1-20. [CrossRef] [PubMed]

115. Pennekamp, P.; Karcher, C.; Fischer, A.; Schweickert, A.; Skryabin, B.; Horst, J.; Blum, M.; Dworniczak, B. The ion channel polycystin-2 is required for left-right axis determination in mice. Curr. Biol. 2002, 12, 938-943. [CrossRef]

116. Robbins, D.J.; Fei, D.L.; Riobo, N.A. The Hedgehog signal transduction network. Sci. Signal. 2012, 5, re6. [CrossRef] [PubMed]

117. Reiter, J.F.; Blacque, O.E.; Leroux, M.R. The base of the cilium: Roles for transition fibres and the transition zone in ciliary formation, maintenance and compartmentalization. EMBO Rep. 2012, 13, 608-618. [CrossRef] [PubMed]

118. Willaredt, M.A.; Gorgas, K.; Gardner, H.A.; Tucker, K.L. Multiple essential roles for primary cilia in heart development. Cilia 2012, 1, 23. [CrossRef] [PubMed]

119. Guo, X.; Wang, X.F. Signaling cross-talk between TGF-beta/BMP and other pathways. Cell Res. 2009, 19, 71-88. [CrossRef] [PubMed] 
120. Bax, N.A.; Bleyl, S.B.; Gallini, R.; Wisse, L.J.; Hunter, J.; Van Oorschot, A.A.; Mahtab, E.A.; Lie-Venema, H.; Goumans, M.J.; Betsholtz, C.; et al. Cardiac malformations in Pdgfralpha mutant embryos are associated with increased expression of WT1 and Nkx2.5 in the second heart field. Dev. Dyn. 2010, 239, 2307-2317. [CrossRef] [PubMed]

121. Tallquist, M.D.; Soriano, P. Cell autonomous requirement for PDGFRalpha in populations of cranial and cardiac neural crest cells. Development 2003, 130, 507-518. [CrossRef] [PubMed]

122. Schatteman, G.C.; Motley, S.T.; Effmann, E.L.; Bowen-Pope, D.F. Platelet-derived growth factor receptor alpha subunit deleted Patch mouse exhibits severe cardiovascular dysmorphogenesis. Teratology 1995, 51, 351-366. [CrossRef] [PubMed]

123. Jin, X.; Mohieldin, A.M.; Muntean, B.S.; Green, J.A.; Shah, J.V.; Mykytyn, K.; Nauli, S.M. Cilioplasm is a cellular compartment for calcium signaling in response to mechanical and chemical stimuli. Cell. Mol. Life Sci. 2014, 71, 2165-2178. [CrossRef] [PubMed]

124. Delling, M.; Indzhykulian, A.A.; Liu, X.; Li, Y.; Xie, T.; Corey, D.P.; Clapham, D.E. Primary cilia are not calcium-responsive mechanosensors. Nature 2016, 531, 656-660. [CrossRef] [PubMed]

125. Nauli, S.M.; Pala, R.; Kleene, S.J. Calcium channels in primary cilia. Curr. Opin. Nephrol. Hypertens. 2016, 25, 452-458. [CrossRef] [PubMed]

126. Siroky, B.J.; Ferguson, W.B.; Fuson, A.L.; Xie, Y.; Fintha, A.; Komlosi, P.; Yoder, B.K.; Schwiebert, E.M.; Guay-Woodford, L.M.; Bell, P.D. Loss of primary cilia results in deregulated and unabated apical calcium entry in ARPKD collecting duct cells. Am. J. Physiol. Renal. Physiol. 2006, 290, 1320-1328. [CrossRef] [PubMed]

127. Liu, W.; Murcia, N.S.; Duan, Y.; Weinbaum, S.; Yoder, B.K.; Schwiebert, E.; Satlin, L.M. Mechanoregulation of intracellular Ca2+ concentration is attenuated in collecting duct of monocilium-impaired orpk mice. Am. J. Physiol. Renal. Physiol. 2005, 289, F978-F988. [CrossRef] [PubMed]

128. Stahmann, N.; Woods, A.; Spengler, K.; Heslegrave, A.; Bauer, R.; Krause, S.; Viollet, B.; Carling, D.; Heller, R. Activation of AMP-activated protein kinase by vascular endothelial growth factor mediates endothelial angiogenesis independently of nitric-oxide synthase. J. Biol. Chem. 2010, 285, 10638-10652. [CrossRef] [PubMed]

129. Chen, Y.; Jiang, B.; Zhuang, Y.; Peng, H.; Chen, W. Differential effects of heat shock protein 90 and serine 1179 phosphorylation on endothelial nitric oxide synthase activity and on its cofactors. PLoS ONE 2017, 12, e0179978. [CrossRef] [PubMed]

130. Siragusa, M.; Frohlich, F.; Park, E.J.; Schleicher, M.; Walther, T.C.; Sessa, W.C. Stromal cell-derived factor 2 is critical for Hsp90-dependent eNOS activation. Sci. Signal. 2015, 8, 81. [CrossRef] [PubMed]

131. Prodromou, N.V.; Thompson, C.L.; Osborn, D.P.; Cogger, K.F.; Ashworth, R.; Knight, M.M.; Beales, P.L.; Chapple, J.P. Heat shock induces rapid resorption of primary cilia. J. Cell Sci. 2012, 125, 4297-4305. [CrossRef] [PubMed]

132. Takahashi, S.; Mendelsohn, M.E. Synergistic activation of endothelial nitric-oxide synthase (eNOS) by HSP90 and Akt: Calcium-independent eNOS activation involves formation of an HSP90-Akt-CaM-bound eNOS complex. J. Biol. Chem. 2003, 278, 30821-30827. [CrossRef] [PubMed]

133. Takahashi, S.; Mendelsohn, M.E. Calmodulin-dependent and -independent activation of endothelial nitric-oxide synthase by heat shock protein 90. J. Biol. Chem. 2003, 278, 9339-9344. [CrossRef] [PubMed]

134. Zeng, C.; Armando, I.; Luo, Y.; Eisner, G.M.; Felder, R.A.; Jose, P.A. Dysregulation of dopamine-dependent mechanisms as a determinant of hypertension: Studies in dopamine receptor knockout mice. Am. J. Physiol. Heart Circ. Physiol. 2008, 294, 551-569. [CrossRef] [PubMed]

135. Zimlichman, R.; Levinson, P.D.; Kelly, G.; Stull, R.; Keiser, H.R.; Goldstein, D.S. Derivation of urinary dopamine from plasma dopa. Clin. Sci. (Lond.) 1988, 75, 515-520. [CrossRef] [PubMed]

136. Baines, A.D.; Chan, W. Production of urine free dopamine from DOPA; a micropuncture study. Life Sci. 1980, 26, 253-259. [CrossRef]

137. Goldstein, M.; Fuxe, K.; Hokfelt, T. Characterization and tissue localization of catecholamine synthesizing enzymes. Pharmacol. Rev. 1972, 24, 293-309. [PubMed]

138. Leaf, A.; Von Zastrow, M. Dopamine receptors reveal an essential role of IFT-B., KIF17, and Rab23 in delivering specific receptors to primary cilia. eLife 2015, 4. [CrossRef] [PubMed] 
139. Upadhyay, V.S.; Muntean, B.S.; Kathem, S.H.; Hwang, J.J.; Aboualaiwi, W.A.; Nauli, S.M. Roles of dopamine receptor on chemosensory and mechanosensory primary cilia in renal epithelial cells. Front. Physiol. 2014, 5, 72. [CrossRef] [PubMed]

140. Domire, J.S.; Green, J.A.; Lee, K.G.; Johnson, A.D.; Askwith, C.C.; Mykytyn, K. Dopamine receptor 1 localizes to neuronal cilia in a dynamic process that requires the Bardet-Biedl syndrome proteins. Cell. Mol. Life Sci. 2011, 68, 2951-2960. [CrossRef] [PubMed]

141. Marley, A.; von Zastrow, M. DISC1 regulates primary cilia that display specific dopamine receptors. PLoS ONE 2010, 5, e10902. [CrossRef] [PubMed]

142. Johns, D.W.; Ayers, C.R.; Carey, R.M. The dopamine agonist bromocriptine induces hypotension by venous and arteriolar dilation. J. Cardiovasc. Pharmacol. 1984, 6, 582-587. [CrossRef] [PubMed]

143. Patch, C.; Charlton, J.; Roderick, P.J.; Gulliford, M.C. Use of antihypertensive medications and mortality of patients with autosomal dominant polycystic kidney disease: A population-based study. Am. J. Kidney Dis. 2011, 57, 856-862. [CrossRef] [PubMed]

144. Barendregt, J.N.; Florijn, K.W.; Muizert, Y.; Chang, P.C. Borderline hypertensive autosomal dominant polycystic kidney disease patients have enhanced production of renal dopamine. Normalization of renal haemodynamics by DOPA infusion. Nephrol. Dial. Transplant. 1995, 10, 1332-1341. [PubMed]

145. Lorthioir, A.; Joannides, R.; Remy-Jouet, I.; Freguin-Bouilland, C.; Iacob, M.; Roche, C.; Monteil, C.; Lucas, D.; Renet, S.; Audrezet, M.P.; et al. Polycystin deficiency induces dopamine-reversible alterations in flow-mediated dilatation and vascular nitric oxide release in humans. Kidney Int. 2015, 87, 465-472. [CrossRef] [PubMed]

146. Kathem, S.H.; Mohieldin, A.M.; Abdul-Majeed, S.; Ismail, S.H.; Altaei, Q.H.; Alshimmari, I.K.; Alsaidi, M.M.; Khammas, H.; Nauli, A.M.; Joe, B.; et al. Ciliotherapy: A novel intervention in polycystic kidney disease. J. Geriatr. Cardiol. 2014, 11, 63-73. [CrossRef] [PubMed]

147. Dummer, A.; Rol, N.; Szulcek, R.; Kurakula, K.; Pan, X.; Visser, B.I.; Bogaard, H.J.; DeRuiter, M.C.; Goumans, M.J.; Hierck, B.P. Endothelial dysfunction in pulmonary arterial hypertension: Loss of cilia length regulation upon cytokine stimulation. Pulm. Circ. 2018, 8. [CrossRef] [PubMed]

148. Kim, K.; Drummond, I.; Ibraghimov-Beskrovnaya, O.; Klinger, K.; Arnaout, M.A. Polycystin 1 is required for the structural integrity of blood vessels. Proc. Natl. Acad. Sci. USA 2000, 97, 1731-1736. [CrossRef] [PubMed]

149. Kathem, S.H.; Mohieldin, A.M.; Nauli, S.M. The Roles of Primary cilia in Polycystic Kidney Disease. AIMS Mol. Sci. 2014, 1, 27-46. [CrossRef] [PubMed]

150. Rossetti, S.; Chauveau, D.; Kubly, V.; Slezak, J.M.; Saggar-Malik, A.K.; Pei, Y.; Ong, A.C.; Stewart, F.; Watson, M.L.; Bergstralh, E.J.; et al. Association of mutation position in polycystic kidney disease 1 (PKD1) gene and development of a vascular phenotype. Lancet 2003, 361, 2196-2201. [CrossRef]

151. Sung, P.H.; Yang, Y.H.; Chiang, H.J.; Chiang, J.Y.; Chen, C.J.; Liu, C.T.; Yu, C.M.; Yip, H.K. Risk of aortic aneurysm and dissection in patients with autosomal-dominant polycystic kidney disease: A nationwide population-based cohort study. Oncotarget 2017, 8, 57594-57604. [CrossRef] [PubMed]

152. Cagnazzo, F.; Gambacciani, C.; Morganti, R.; Perrini, P. Intracranial aneurysms in patients with autosomal dominant polycystic kidney disease: Prevalence, risk of rupture, and management. A. systematic review. Acta Neurochir. (Wien.) 2017, 159, 811-821. [CrossRef] [PubMed]

153. Neves, J.B.; Rodrigues, F.B.; Lopes, J.A. Autosomal dominant polycystic kidney disease and coronary artery dissection or aneurysm: A. systematic review. Ren. Fail. 2016, 38, 493-502. [CrossRef] [PubMed]

154. Kanagasundaram, N.S.; Perry, E.P.; Turney, J.H. Aneurysm of the splenic artery in a patient with autosomal dominant polycystic kidney disease. Nephrol. Dial. Transplant. 1999, 14, 183-184. [CrossRef] [PubMed]

155. Liu, M.; Zhao, J.; Zhou, Q.; Peng, Y.; Zhou, Y.; Jiang, Y. Primary Cilia Deficiency Induces Intracranial Aneurysm. Shock 2018, 49, 604-611. [CrossRef] [PubMed]

156. Dolan, J.M.; Meng, H.; Singh, S.; Paluch, R.; Kolega, J. High fluid shear stress and spatial shear stress gradients affect endothelial proliferation, survival, and alignment. Ann. Biomed. Eng. 2011, 39, 1620-1631. [CrossRef] [PubMed]

157. Kuhlencordt, P.J.; Gyurko, R.; Han, F.; Scherrer-Crosbie, M.; Aretz, T.H.; Hajjar, R.; Picard, M.H.; Huang, P.L. Accelerated atherosclerosis, aortic aneurysm formation, and ischemic heart disease in apolipoprotein E/endothelial nitric oxide synthase double-knockout mice. Circulation 2001, 104, 448-454. [CrossRef] [PubMed] 
158. Chen, X.; Gays, D.; Milia, C.; Santoro, M.M. Cilia Control Vascular Mural Cell Recruitment in Vertebrates. Cell Rep. 2017, 18, 1033-1047. [CrossRef] [PubMed]

159. Jones, T.J.; Adapala, R.K.; Geldenhuys, W.J.; Bursley, C.; AbouAlaiwi, W.A.; Nauli, S.M.; Thodeti, C.K. Primary cilia regulates the directional migration and barrier integrity of endothelial cells through the modulation of hsp27 dependent actin cytoskeletal organization. J. Cell. Physiol. 2012, 227, 70-76. [CrossRef] [PubMed]

160. Caro, C.G. Discovery of the role of wall shear in atherosclerosis. Arterioscler. Thromb. Vasc. Biol. 2009, 29, 158-161. [CrossRef] [PubMed]

161. Suo, J.; Ferrara, D.E.; Sorescu, D.; Guldberg, R.E.; Taylor, W.R.; Giddens, D.P. Hemodynamic shear stresses in mouse aortas: Implications for atherogenesis. Arterioscler. Thromb. Vasc. Biol. 2007, 27, 346-351. [CrossRef] [PubMed]

162. Dinsmore, C.; Reiter, J.F. Endothelial primary cilia inhibit atherosclerosis. EMBO Rep. 2016, 17, $156-166$. [CrossRef] [PubMed]

163. Rabelink, T.J.; Luscher, T.F. Endothelial nitric oxide synthase: Host defense enzyme of the endothelium? Arterioscler. Thromb. Vasc. Biol. 2006, 26, 267-271. [CrossRef] [PubMed]

164. Cunningham, K.S.; Gotlieb, A.I. The role of shear stress in the pathogenesis of atherosclerosis. Lab. Investig. 2005, 85, 9-23. [CrossRef] [PubMed]

165. Kawashima, S.; Yokoyama, M. Dysfunction of endothelial nitric oxide synthase and atherosclerosis. Arterioscler. Thromb. Vasc. Biol. 2004, 24, 998-1005. [CrossRef] [PubMed]

166. Ishikawa, H.; Marshall, W.F. Ciliogenesis: Building the cell's antenna. Nat. Rev. Mol. Cell Biol. 2011, 12, 222-234. [CrossRef] [PubMed]

167. Goto, H.; Inaba, H.; Inagaki, M. Mechanisms of ciliogenesis suppression in dividing cells. Cell. Mol. Life Sci. 2017, 74, 881-890. [CrossRef] [PubMed]

168. Izawa, I.; Goto, H.; Kasahara, K.; Inagaki, M. Current topics of functional links between primary cilia and cell cycle. Cilia 2015, 4, 12. [CrossRef] [PubMed]

169. Ke, Y.N.; Yang, W.X. Primary cilium: An elaborate structure that blocks cell division? Gene 2014, 547, $175-185$. [CrossRef] [PubMed]

170. Goto, H.; Inoko, A.; Inagaki, M. Cell cycle progression by the repression of primary cilia formation in proliferating cells. Cell. Mol. Life Sci. 2013, 70, 3893-3905. [CrossRef] [PubMed]

171. Plotnikova, O.V.; Golemis, E.A.; Pugacheva, E.N. Cell cycle-dependent ciliogenesis and cancer. Cancer Res. 2008, 68, 2058-2061. [CrossRef] [PubMed]

172. Bhunia, A.K.; Piontek, K.; Boletta, A.; Liu, L.; Qian, F.; Xu, P.N.; Germino, F.J.; Germino, G.G. PKD1 induces p21(waf1) and regulation of the cell cycle via direct activation of the JAK-STAT signaling pathway in a process requiring PKD2. Cell 2002, 109, 157-168. [CrossRef]

173. Gradilone, S.A.; Pisarello, M.J.L.; LaRusso, N.F. Primary Cilia in Tumor Biology: The Primary Cilium as a Therapeutic Target in Cholangiocarcinoma. Curr. Drug Targets 2017, 18, 958-963. [CrossRef] [PubMed]

174. Barakat, M.T.; Humke, E.W.; Scott, M.P. Kif3a is necessary for initiation and maintenance of medulloblastoma. Carcinogenesis 2013, 34, 1382-1392. [CrossRef] [PubMed]

175. Castiella, T.; Munoz, G.; Luesma, M.J.; Santander, S.; Soriano, M.; Junquera, C. Primary cilia in gastric gastrointestinal stromal tumours (GISTs): An ultrastructural study. J. Cell. Mol. Med. 2013, 17, 844-853. [CrossRef] [PubMed]

176. Rocha, C.; Papon, L.; Cacheux, W.; Marques Sousa, P.; Lascano, V.; Tort, O.; Giordano, T.; Vacher, S.; Lemmers, B.; Mariani, P.; et al. Tubulin glycylases are required for primary cilia, control of cell proliferation and tumor development in colon. EMBO J. 2014, 33, 2247-2260. [CrossRef] [PubMed]

(C) 2018 by the authors. Licensee MDPI, Basel, Switzerland. This article is an open access article distributed under the terms and conditions of the Creative Commons Attribution (CC BY) license (http:/ / creativecommons.org/licenses/by/4.0/). 